\title{
ФОРМУВАННЯ ЕКОЛОГІЧНОЇ КОМПЕТЕНТНОСТІ ЯК СКЛАДНИКА ПРОФЕСІЙНОӤ ПІДГОТОВКИ МАГІСТРІВ ОСВІТИ
}

\author{
Джура Н. М. \\ кандидат біологічних наук, доцент, \\ доиент кафедри екологіі \\ Львівський наџіональний університет імені Івана Франка \\ вул. Університетська, 1, Львів, Україна \\ orcid.org/0000-0001-9170-6014 \\ nataliya.dzhura@lnu.edu.ua \\ Нагірнич О. М. \\ студентка I курсу магістратури \\ Львівський національний університет імені Івана Франка \\ вул. Університетська, 1, Львів, Украӥна \\ orcid.org/0000-0001-5722-6607 \\ nahirnysh19@ukr.net
}

\begin{abstract}
Ключові слова: магістр освіти, екологічна компетентність, професійна підготовка, екологічна освіта, сталий розвиток, довкілля, екоосвітня діяльність.
\end{abstract}

Статтю присвячено актуальній нині проблемі формування екологічної компетентності як складової частини професійної підготовки магістрів освіти, які зможуть забезпечувати викладацьку, наукову і методичну діяльність у закладах середньої та вищої освіти. На біологічному факультеті Львівського національного університету імені Івана Франка готують бакалаврів і магістрів за предметною спеціальністю 014.05 Середня освіта (Біологія та здоров’я людини). В умовах антропогенного тиску на довкілля і загострення екологічних проблем виникає потреба переосмислити i переглянути зміст екологічної освіти майбутніх фахівців - учителів біології, хімії та здоров'я людини. Професійну екологічну компетентність доцільно формувати через екологізацію навчального процесу у вищій школі. Запропоновано для магістрів освіти включити до навчального плану курс «Екологічна культура»; у змісті лекційного матеріалу 3 курсів «Біорізноманіття рослин» i «Біорізноманіття тварин» - розглянути питання про сучасний вплив людини на різноманіття рослин і тварин на глобальному рівні; у змісті лекційного матеріалу з курсу «Генетика людини» - питання про вплив антропогенних факторів довкілля на мутації генів та їх наслідки.

Формування екологічної компетентності $є$ одним із найважливіших завдань освіти сталого розвитку. Проаналізовано місце освіти у сталому розвитку в новій українській школі, головна мета якої - створити школу, у якій буде приємно навчатися і яка даватиме учням не тільки знання, як це відбувається зараз, а й уміння застосовувати їх у повсякденному житті. Саме тому для магістрів освіти запропоновано вивчати курс «Екоосвітня діяльність для сталого розвитку». Така навчальна дисципліна сприятиме системному узагальненню екологічного й педагогічного досвіду, формуванню у майбутніх педагогів готовності до роботи зі здобувачами освіти на засадах сталого розвитку, вміння фахово застосовувати теоретичні знання в освітньому процесі 3 метою виховання у молоді ціннісного ставлення до довкілля й екологічного стилю життя. 


\title{
FORMATION OF ENVIRONMENTAL COMPETENCE AS A COMPONENT OF PROFESSIONAL TRAINING FOR MASTERS OF EDUCATION
}

\author{
Dzhura N. M. \\ Candidate of Biological Sciences, Associate Professor \\ Associate Professor at the Department of Ecology \\ Ivan Franko National University of Lviv \\ Universytetska str., 1, Lviv, Ukraine \\ orcid.org/0000-0001-9170-6014 \\ nataliya.dzhura@lnu.edu.ua \\ Nahirnych O. M. \\ 1st year Master Student \\ Ivan Franko National University of Lviv \\ Universytetska str., 1, Lviv, Ukraine \\ orcid.org/0000-0001-5722-6607 \\ nahirnysh19@ukr.net
}

Key words: Master of

Education, environmental competence, professional training, environmental education, sustainable development, environment, environmental education activity.
The article is devoted to the topical issue of forming environmental competence as a component of professional training for Masters of Education who are trained for teaching, methodological and research work in institutions of secondary and higher education.

Faculty of Biology at Ivan Franko National University of Lviv trains bachelors and masters in the subject area 014.05 Secondary Education (Biology and Human Health). In the conditions of anthropogenic pressure on the environment and aggravation of environmental problems, a need to rethink and review the content of environmental training for future teachers of biology, chemistry and human health arises. Professional environmental competence is proposed to be formed through environmentalization of the main teaching and learning forms in higher educational institutions (lectures, seminars, laboratory classes, fieldwork and pedagogical practice). It is proposed to introduce certain changes to the curriculum of Masters of Education: to include the course "Environmental Culture" into the curriculum; to consider the issue of current human impact on plant diversity at the global level in the lecture content of the course "Plant Biodiversity"; to consider the influence of anthropogenic environmental factors on gene mutations and their consequences in the lecture content of the course "Human Genetics".

Formation of environmental competence is one of the main tasks of education for sustainable development. The article analyses the role of education for sustainable development in the New Ukrainian School, the main goal of which is to create a school that will be pleasant to study in and will provide the students not only with the knowledge, as it does now, but also with the ability to apply it in everyday life. For this reason, it is proposed to consider including the course "Environmental Education Activity For Sustainable Development" into the curriculum of Masters of Education. Such an academic discipline will systematise and generalise environmental and pedagogical experience and promote the formation of future teachers' readiness to work with learners on the principles of sustainable development, the ability to apply theoretical knowledge in the educational process in order to educate young learners about the values-based attitude to the environment and sustainable living. 
Постановка проблеми. Однією 3 передумов вирішення екологічних проблем сучасності $\epsilon$ розвиток екологічної компетентності особистості, важливу роль у формуванні якої відіграють загальноосвітні навчальні заклади. Шлях до підвищення рівня екологічної культури учнів лежить через ефективну екологічну освіту, якість якої значною мірою залежить від професійної підготовки вчителів $[1 ; 4 ; 8 ; 9 ; 10]$.

На біологічному факультеті Львівського національного університету імені Івана Франка з 2018 року здійснюють підготовку здобувачів другого рівня вищої освіти (магістрів) за освітньо-професійною програмою «Середня освіта (біологія та здоров'я людини)» предметної спеціальності 014.05 Середня освіта (Біологія та здоров'я людини) галузі знань 01 Освіта / Педагогіка. Випускникам освітньої програми присвоюють кваліфікацію «Магістр освіти. Вчитель біології, хімії та здоров'я людини» [13].

Екологічну компетентність студентів педагогічних спеціальностей визначають як здатність застосовувати екологічні знання й досвід у професійних i життєвих ситуаціях, керуючись пріоритетністю екологічних цінностей і усвідомлення особистої причетності до екологічних проблем і відповідальності за наслідки своєї діяльності [8; 9].

В умовах антропогенного тиску на довкілля i загострення екологічних проблем виникає потреба переосмислити і переглянути зміст професійної підготовки майбутніх фахівців - учителів біології, хімії та здоров'я людини. Адже педагоги як учасники навчально-виховного процесу є провідними генераторами розвитку екологічної грамотності молоді $[1 ; 3 ; 4 ; 7]$. Тому проблема формування екологічної компетентності як складника професійної підготовки магістрів освіти є актуальною та потребує подальшого висвітлення.

Мета статті. Обгрунтувати необхідність формування екологічної компетентності як складової частини професійної підготовки магістрів освіти (вчителів біології, хімії та здоров'я людини), які зможуть забезпечувати викладацьку, наукову i методичну діяльність у закладах середньої та вищої освіти. Запропонувати умови для якісного формування екологічної компетентності здобувачів освіти у межах освітньо-професійної програми «Середня освіта (біологія та здоров'я людини)».

Виклад основного матеріалу. Зміст і організація сучасної освіти орієнтуються на формування у молоді життєво важливих компетентностей. У цьому процесі ключову роль відіграє екологічна компетентність самих педагогів. У iі формуванні провідна роль належить закладам вищої освіти, які забезпечують утвердження екологічного світогляду і розвиток екологічної культури майбутніх учителів. Усе це у подальшому дасть можливість кваліфікованим педагогам розвивати такі якості в учнів $[5 ; 6]$.

Пріоритетна мета української системи освіти - створення умов для розвитку та самореалізації кожної особистості як громадянина України, формування покоління, здатного навчатися впродовж життя, створювати й розвивати цінності громадянського суспільства. Це можливо лише за умови якісної освіти. Згідно 3 концепцією Нової української школи (НУШ) центральне місце у системі освіти належить середній школі, де формується особистість, іiі громадянська позиція та моральні якості. Формула НУШ складається 3 ключових компонентів, серед яких важливим $€$ набуття компетентностей для життя [5; 11].

Компетентність розглядають як динамічну комбінацію знань, способів мислення, поглядів, цінностей, навичок, умінь, інших особистих якостей, що визначає здатність особи успішно провадити професійну та/або подальшу навчальну діяльність [5].

Серед 10 компетентностей НУШ є Екологічна грамотність $i$ здорове життя. Зміст цієї компетентності передбачає вміння учнів описувати основні ознаки концепції сталого розвитку; можливі ризики майбутнього за вибраними ознаками; порівнювати різні сценарії і ризики прогнозованого майбутнього; складати схеми причинно-наслідкових зв'язків; висловлювати судження щодо впливу людських дій на ймовірність реалізації сценаріїв майбутнього [5; 11].

На жаль, сьогодні з навчальних планів середньої загальноосвітньої школи вилучено предмет «Екологія». Тому для реалізації компетентності «Екологічна грамотність $i$ здорове життя» пропонуємо включити факультативний курс «Освіта для сталого розвитку». Цей курс зможе забезпечити окремі ключові компетентності НУШ, зокрема: уміння генерувати нові ідеї та ініціативи i втілювати їх у життя 3 метою як підвищення власного соціального статусу та добробуту, так i розвитку суспільства і держави; уміння розумно та раціонально користуватися природними ресурсами у межах сталого розвитку; усвідомлення ролі навколишнього середовища для життя і здоров'я людини, здатність і бажання дотримуватися здорового способу життя тощо [11; 12].

Оволодіння учнями компетентністю «Екологічна грамотність $i$ здорове життя» неможливе без попереднього оволодіння нею педагогами. Тому для майбутніх учителів біології, хімії та основ здоров'я пропонуємо вивчати курс «Екоосвітня діяльність для сталого розвитку» 3 метою привернення уваги до основних проблем довкілля і можливостей їхнього вирішення. У курсі пропонуємо вивчати матеріал у межах двох змістових модулів (3М): ЗМ 1. Екологічна освіта для сталого 
розвитку в системі професійної підготовки педагога; 3М 2. Новітні екоосвітні технології. Така навчальна дисципліна сприятиме системному узагальненню екологічного й педагогічного досвіду, формуванню у магістрів освіти готовності до роботи зі здобувачами освіти на засадах сталого розвитку, вміння фахово застосовувати теоретичні знання для обгрунтованого переконання й формування ціннісного ставлення до довкілля, екологічного стилю життя.

На формування екологічного світогляду майбутніх учителів біології, хімії та здоров'я людини, на нашу думку, впливають такі умови організації освітнього процесу у ЗВО, як: 1) професійна підготовка магістрів освіти, яку можна безпосередньо організувати на біологічному факультеті ЛНУ імені Івана Франка, зокрема оновлення освітньої програми 3 акцентом на екологізацію окремих компонентів (навчальних дисциплін); 2) педагогічна взаємодія у системі «викладач - студент» 3 урізноманітненням інтерактивних форм і методів викладання; 3) умови, які діють за межами ЗВО.

Під час аналізу ОПП підготовки магістрів освіти за спеціальністю 014.05 Середня освіта (Біологія та здоров'я людини) серед компонентів предметної спеціальності виявили такі: «Біорізноманіття рослин», «Біорізноманіття тварин», «Системна фізіологія», «Актуальні проблеми фітофізіології у системі викладання біології», «Генетика людини» [13]. Для якісного формування екологічної компетентності як складника професійної підготовки магістрів освіти пропонуємо ввести навчальну дисципліну «Екологічна культура» 3 метою набуття студентами екологічних знань, виховання екологічної грамотності та формування у них природозбережувальних принципів поведінки у довкіллі. У змісті лекційного матеріалу з курсів «Біорізноманіття рослин» i «Біорізноманіття тварин» важливо розглянути питання про сучасний вплив людини на розмаїття рослин і тварин на глобальному рівні. У зміст лекційного матеріалу з курсу «Генетика людини» рекомендуємо до розгляду питання про вплив антропогенних факторів довкілля на мутації генів та їх наслідки.

Професійна екологічна компетентність розвивається на основі наукових екологічних знань. Важливими під час її формування є екологізація змісту основних форм організації навчального процесу у вищій школі: лекцій, лабораторних i практичних занять, польових і педагогічних практик $[6 ; 8]$. Магістри освіти повинні бути готові до прийняття екологічно виважених рішень та відповідальності за власні дії. Ці інтегрувальні елементи є системотворчими для формування екологічної компетентності студентів [8; 9]. Для виконання таких умов необхідно урізноманітню- вати навчальний процес інтерактивними формами i методами викладання [2]. Під час практичних i семінарських занять доцільно використовувати сучасні технології: практико-спрямовані завдання, семінари-дискусії, тренінги, тьюторингові та менторингові практики; кейс-методи аналізу конкретних екологічних ситуацій, прес-конференції, мозковий штурм, роботу в командах, метод проектів тощо.

Польова практика належить до дослідницько-практичної діяльності, а тому має важливе значення у професійній підготовці магістрів освіти. Це одна 3 найефективніших форм організації навчально-виховного процесу в закладах вищої освіти, під час якої закріплюються набуті на лекціях, семінарах і лабораторно-практичних заняттях теоретичні знання, формуються уміння спостерігати та аналізувати об'єкти і явища, встановлювати взаємозв'язки, оцінювати наслідки природокористування, продукувати ідеї щодо охорони довкілля [4; 8; 9].

Серед переліку компонентів освітньої програми спеціальності 014.05 середня освіта (Біологія і здоров'я людини) передбачено проходження студентами педагогічної практики у третьому семестрі тривалістю шість тижнів. Вважаємо доцільним для магістрів освіти окрім вищезазначеної практики додати два тижні польової практики наприкінці 2 семестру або урізноманітнити шеститижневу практику за схемою: 4 тижні педагогічна, 2 тижні - польова. Пропонуємо два змістові блоки для польової практики. Проведення першого блоку передбачає ознайомлення із біорізноманіттям Львівської області та шляхами його збереження на основі екскурсій до національних природних парків та заповідників області. Проведенню цього блоку польової практики передує вивчення дисциплін: «Біорізноманіття рослин» i «Біорізноманіття тварин». Другий блок польової практики передбачає долучення студентів до організації еколого-просвітнього заходу на рівні міста. Тематику заходу та його програму розробляють студенти під керівництвом викладача, що відповідає за проведення практики.

Ознайомлення 3 різними думками, попередня робота 3 тематичною літературою та пошук креативних шляхів розв'язання проблеми допоможе студентам розширити екологічний світогляд, набути навичок організації подібних заходів та сприятиме формуванню у них практичної готовності до екологічної діяльності у закладах середньої та вищої освіти.

Формування екологічної компетентності студентів передбачає утвердження певних моральних принципів та поглядів, розуміння відповідальності за власні дії. Тут важливе значення має залучення студентів до екологічних акцій, 
майстер-класів, екскурсій та інших заходів екоосвітнього й екопросвітнього спрямування [12].

У світовій практиці збереження природних територій усе більшого визнання набуває підхід до багатоцільового використання природно-заповідних територій. Одним із способів залучення молоді до самостійного пізнання природи $\epsilon$ створення пізнавально-туристичних екологічних стежок. Спеціально облаштовані прогулянково-пізнавальні маршрути, що перебувають під особливою охороною, створюють із метою екологічної просвіти населення через встановлені інформаційні стенди. Екологічні стежки прокладають у зонах організованого туризму, національних парках, ландшафтних заповідниках тощо [3]. Вважаємо, що використання екологічної стежки у навчальному процесі сприятиме узагальненню знань студентів, набутих під час вивчення природничих дисциплін; створенню умов для виховання екологічно грамотної поведінки у довкіллі; організації науково-дослідницької діяльності; розвиткові умінь аналізувати, обгрунтовувати, проектувати, рефлексувати, виявляти закономірності життя природних екосистем; оцінювати та прогнозувати екологічні наслідки антропогенного впливу на довкілля. Роботу на екологічній стежці зі студентами можна організовувати під час проходження як польової, так і педагогічної практики, а також у межах запропонованого курсу «Екологічна культура». У подальшому майбутні педагоги зможуть використати набутий досвід під час освітньо-виховного процесу з учнями у ЗОШ. Одним із творчих завдань для магістрів освіти можна запропонувати розробити маршрут екологічної стежки свого регіону. Як приклад наводимо розроблену екологічну стежку «Перлина Карпат», яка знаходиться у Дрогобицькому районі Львівської області та містить такі зупинки: зупинка 1 - водоспад Лазний; зупинка 2 - водоспад Сопіт; зупинка 3 - «Екосистема ріки Стрий»; зупинка 4 - історико-культурний заповідник «Тустань».

Під час організації освітнього процесу в умовах дистанційного навчання зі студентами можна організовувати вебінари - інтерактивні семінари 3 використанням інтернет-технологій із залученням зацікавленої аудиторії. Під час вебінару викладач доповідає і відповідає на питання слухачів. Відеозапис заходу можна застосовувати у подальшому навчанні.

Пропонуємо екологічну тематику для вебінарів: «Сміття чи відходи? Утилізація та сортування для збереження природи», «Природні джерела енергії: «за» та «проти», «Глобальна зміна клімату та її наслідки», «Альтернативна енергетика», «Наслідки вирубування лісів», «Джерела забруднення Світового океану та способи їх мінімізації», «Спалювання стерні та сухої трави. Шкода для довкілля», «Збереження біорізноманіття як основа збереження життя на Землі», «Довкілля та здоров'я», «Життя у стилі «еко», «Екологічний стандарт «Зелений клас»»».

Висновки. Екологічну безпеку суспільства тісно пов'язують із рівнем освіченості, культури та виховання громадян. Екологічна компетентність як складова частина загальної компетентності магістра освіти (вчителя біології, хімії та здоров'я людини) $є$ визначальною у формуванні природоцентричного світогляду, турботи і відповідальності за довкілля і вихованні екологічно свідомого суспільства. Вважаємо, що вирішення ключових питань розвитку освіти і створення належних умов для надання якісних освітніх послуг має відбуватися завдяки співпраці закладів вищої освіти і середньої загальноосвітньої школи, спільних зусиль керівників навчальних закладів і вчителів, які глибоко розуміють освітні та екологічні проблеми в конкретному регіоні. 3 цією метою необхідно періодично оновлювати освітні програми, враховуючи проблеми сьогодення, і передбачати механізми введення таких навчальних дисциплін, які би сприяли розвиткові екологічно грамотного суспільства. Особливу увагу слід звертати на професійне вдосконалення педагогів та здобувачів освіти у ЗВО, адже якісна екологічна освіта - необхідна умова для збереження довкілля та забезпечення сталого розвитку суспільства.

\section{ЛІТЕРАТУРА}

1. Баюрко Н.В. Формування готовності майбутніх учителів біології до розвитку екологічної компетентності учнів основної школи. Nowoczesna edukacja: filozofia, innowacja, doświadczenie. $\mathrm{Nr} 2(6)$. Łódź : Wydawnictwo Naukowe Wyższej Szkoły Informatyki i Umiejętności, 2016. P. 157-161.

2. Джура Н. Організація екоосвітньої діяльності для сталого розвитку в умовах загальноосвітньої школи. Вісник Львівського університету. 2019. Випуск 34. С. 52-62.

3. Жданова С.А. Формирование экологической компетентности специалиста дошкольного образовательного учреждения в процессе повышения квалификации : дис. ... канд. пед. наук : 13.00.08. Шуя, 2009. $261 \mathrm{c.}$

4. Колонькова О.О. Формування екологічної компетентності у студентів-екологів. Педагогічний проиес: теорія і практика. 2007. № 1. С. 55-64.

5. Концепція нової української школи. Інформаційний збірник Міністерства освіти і науки. 2016. C. 5-13. 
6. Кунинець О.Б., Джура Н.М. Екологізація вищої освіти для сталого розвитку. Матеріали V Міжнародної наукової конференції студентів, аспірантів та молодих вчених «Фундаментальні та прикладні дослідження в біології та екологї̈» (7-8 листопада 2018 р., м. Вінниця). Вінниця, 2018. C. $101-102$.

7. Мелаш В., Ковальчук К. Теоретико-методичні засади формування екологічної компетентності молодших школярів. Науковий вісник Мелітопольського державного педагогічного університету. 2013. № 1 (10). С. 118-121.

8. Панфилова Л.В. Формирование экологической компетентности в процессе профессиональной подготовки учителя химии : дис. ... д-ра пед. наук : 13.00.08. Тольятти, 2002. $481 \mathrm{c.}$

9. Титаренко Л.М. Готовність до екологічної діяльності як засада формування екологічної компетентності студентів / Л. М. Титаренко // Підвищення готовності майбутніх фахівиів до інновачійної педагогічної діяльності : зб. наук. пр. 2005. С. 201-206.

10. Формування екологічної компетентності школярів : наук.-метод. посіб. / за ред. : Н.А. Пустовіт, О.Л. Пруцакова, Л.Д. Руденко, О.О. Колонькова. Київ : «Педагогічна думка», 2008. 64 с.

11. Dzhura N.M. Education for sustainable development in the New Ukrainian School / N.M. Dzhura, Z.I. Mamchur, M. R. Dzhura. 6-й Міжнародний конгрес "Сталий розвиток: захист навколишнього середовища. Енергоощадність. Збалансоване природокористування”: збірник матеріалів. Львів : Західно-Український Консалтинг Центр (ЗУКЦ), ТзОВ, 2020. С. 194.

12. Nahirnych O.M. The importance of environmental education and enlightenment in the upbringing of youth / O.M. Nahirnych, N.R. Meush, M.R. Dzhura, N.M. Dzhura. Природнича наука й освіта: сучасний стан і перспективи розвитку : матеріали II Міжнародної науково-практичної конференції (20-22 вересня 2019 р., м. Харків). Харків : ХНПУ, 2019. С. 14-15.

13. URL: https://bioweb.lnu.edu.ua/wp-content/uploads/2019/11/OPP-Serednia-osvita-biolohiia-ta-zdorovialiudyny-.pdf

\section{REFERENCES}

1. Baiurko N.V. (2016) Formuvannia hotovnosti maibutnikh uchyteliv biolohii do rozvytku ekolohichnoi kompetentnosti uchniv osnovnoi shkoly [Formation of readiness of future biology teachers for the development of environmental competence of secondary school students]. Nowoczesna edukacja: filozofia, innowacja, doświadczenie. Nr 2(6). Łódź: Wydawnictwo Naukowe Wyższej Szkoły Informatyki i Umiejętności. P. 157-161 [in Ukrainian].

2. Dzhura N. (2019) Orhanizatsiia ekoosvitnoi diialnosti dlia staloho rozvytku v umovakh zahalnoosvitnoi shkoly [Organization of environmental education activity for sustainable development in secondary schools]. Visnyk of the Lviv University. Series Pedagogics. Vol. 34. P. 52-62 [in Ukrainian].

3. Zhdanova S.A. (2009) Formirovanie ekolohicheskoi kompetentnosti spetsialista doshkolnoho obrazovatelnoho uchrezhdeniia $\mathrm{v}$ protsesse povysheniia kvalifikatsyi [Formation of environmental competence of preschool education institution specialists in the process of professional upskilling]: dys. ... kand. ped. nauk : 13.00.08. Shuia. $261 \mathrm{p}$ [in Ukrainian].

4. Kolonkova O.O. (2007) Formuvannia ekolohichnoi kompetentnosti u studentiv-ekolohiv [Formation of environmental competence of ecology students]. The Pedagogical Process: Theory and Practice № 1. P. 55-64 [in Ukrainian].

5. Kontseptsiia novoi ukrainskoi shkoly (2016) [The concept of the New Ukrainian school]. Informatsiinyi zbirnyk Ministerstva osvity i nauky. P. 5-13 [in Ukrainian].

6. Kunynets, O.B., Dzhura, N.M. (2018) Ekolohizatsiia vyshchoi osvity dlia staloho rozvytku [Environmentalization of higher education for sustainable development]. Materialy V Mizhnarodnoi naukovoikonferentsiistudentiv, aspirantivta molodykhvchenykh «Fundamentalnitaprykladnidoslidzhennia v biolohii ta ekolohii» (7-8 Nowember 2018., Vinnytsia). Vinnytsia. S. 101-102 [in Ukrainian].

7. Melash V., Kovalchuk K. (2013) Teoretyko-metodychni zasady formuvannia ekolohichnoi kompetentnosti molodshykh shkoliariv [Theoretical and methodological principles of environmental competence formation of primary schoolers]. Scientific Bulletin Melitopol State Pedagogical University. Series: Pedagogy. № 1 (10). P. 118-121 [in Ukrainian].

8. Panfylova L.V. (2002) Formirovanie ekolohicheskoi kompetentnosti v protsesse professionalnoi podhotovki uchitelia khimii [Formation of environmental competence in the process of professional training of chemistry teachers]: dys... d-ra ped. nauk : 13.00.08. Toliatty. $481 \mathrm{p}$ [in Russian].

9. Tytarenko L.M. (2005) Hotovnist do ekolohichnoi diialnosti yak zasada formuvannia ekolohichnoi kompetentnosti studentiv [Readiness for ecological activity as a basis for the formation of students' 
environmental competence]. Pidvyshchennia hotovnosti maibutnikh fakhivtsiv do innovatsiinoi pedahohichnoi diialnosti : zb. nauk. pr. 2005. P. 201-206 [in Ukrainian].

10. Pustovit, N.A., Prutsakova, O.L., Rudenko, L.D., Kolonkova, O.O. (2008). Formuvannia ekolohichnoi kompetentnosti shkoliari [Formation of environmental competence of schoolchildren]. Kyiv: Pedahohichna Dumka. 64 p. [in Ukrainian].

11. Dzhura, N.M., Mamchur, Z.I., Dzhura, M.R. (2020) Education for sustainable development in the New Ukrainian School // 6-th International Congress "Sustainable Development: Protecting the Environment. Energy saving. Balanced nature management": a collection of materials. Lviv : Western Ukrainian Consulting Center (ZUKC), Ltd., 2020. P. 194 [in Ukrainian].

12. Nahirnych, O.M., Meush, N.R., Dzhura, M.R., Dzhura, N.M. (2019) The importance of environmental education and enlightenment in the upbringing of youth / Natural science and education: current state and development prospect: materials of the II International scientific-practical conference (September 20-22, 2019, Kharkiv). Kharkiv : KhNPU. P. 14-15 [in Ukrainian].

13. URL: https://bioweb.lnu.edu.ua/wp-content/uploads/2019/11/OPP-Serednia-osvita-biolohiia-ta-zdorovialiudyny-.pdf 